greater success, for permission to lay a cable between Dover and Calais. On August Io, I849, Louis Napoleon granted them an absolute monopoly for ten years, provided that the wire was laid by September 1,1850 . Before this date a telegraph wire under the Channel became an accomplished fact, and messages were certainly transmitted through it, although they seem to have been slightly incoherent. The glory of this tele. graph was, unfortunately, short-lived, for after the first evening it maintained an obstinate reserve, and "spoke no more."

The next year another concession was granted to the Bretts by the French Government, and on the strength of this the Submarine Telegraph Company was formed. But $£ 300$ was all the public would subscribe, as it had already been conclusively proved that submarine telegraphy was an impossibility. Happily Mr. Crampton came to the rescue, while Mr. Kuiper suggested armouring the insulated conductor with iron sheathing-a proposal also made by Willoughby Smith. Once more England and France were electrically connected, and on November I3, I $85 \mathrm{I}$, the public sent a message through a submarine cable for the first time in the history of the world.

The Bretts then applied to the Government for a monopoly to electrically connect England and Ireland. Prof. Ayrton read out the original replies they received on this occasion, in which each Government department in turn complimented the brothers on their perseverance and success, but regretted that the matter did not lie in their power, and referred them " next door." The laughter that was here heard among the audience was presumably due to the striking contrast this afforded with the promptness and celerity of Government procedure of to-day

As early as I 844 Morse had written to the American Treasury : "My experience is that telegraphic communication on the dectromagnet plan might certainly be established across the Atlantic Ocean." Nothing was done in the matter until 1855 , when a syndicate was formed, and in the following year Cyrus Field crossed over to England, where he signed an agreement with J. W. Brett, Charles Bright, and E. Whitehouse to start an Atlantic Telegraph Company.

Great difficulties foreshadowed the working of an Atlantic cable, due to the retardation of the signals. In connection with this subject, the lecturer stated the very different values which had been assigned by Wheatstone, Latimer Clark, and others to the velocity of electricity, before it had been deduced from a paper of Lord Kelvin's, in 1855, that electricity had no velocity in the ordinary sense of the word.

A mechanical model was shown illustrating the difference between the sudden opening of a door by a ball projected at it with a certain velocity, and the gradual opening of the door by the gradual increase of the pull at the other end of a long piece of india-rubber-the latter method being comparable with the action of an electric current. Experiments were also made on a water cable, and it was shown that by combining resistance and capacity, waves of water travelling in opposite directions could exist at the same time in a tube ; also that if positive and negative pressures were alternately applied on one end of the tube, with an interval of time less than thirteen seconds between their application, no effect whatever could be detected at the other end of the tube, a distance of seven feet. The spots from three very dead-beat galvanometers, placed respectively at the sending, middle, and receiving end of an artificial Pacific cable, were then projected on the screen, and the gradual rise of current along the cable was made visible to every one, the current at the distant end taking six seconds to reach its steady value.

The lecturer here mentioned Fourier's Théorie Analytique de la Chaleur, published in I822, which " mathematical poem," though written long before cables were dreamt of, enabled Kelvin thirty years later to attack a problem, the successful solution of which has created submarine telegraphy. For two other important conclusions were deduced from Kelvin's I 855 paper, namely, that the time elapsing before the current began to appear at the other end of a cable, only depended on the product of the resistance of the conductor into the electrostatic capacity, and practically not at all on the battery power. Also that the retardation of the signals was proportional to the square of the length. The first of these results was opposed to the opinion of such well-known engineers as Sir Charles, and Edward, Bright, who considered that the velocity of electricity varied with the use of high potential frictional, or of low potential voltaic electricity. From his own theory Kelvin calculated that the probable speed of signalling through the proposed Atlantic cable would be at the rate of three words a minute, which was sub- sequently found to be obtainable with his mirror galvanometer. Siemens, however, feared that only one word a minute could be sent, while Charles Bright, from experiments on 2000 miles of underground conductor, predicted ten or twelve.

Meanwhile the Atlantic Telegraph Company had been successful in their efforts, for in 1857 the U.S. frigate Niagara and H.M.S. Agamemnon started from Valentia with 2500 miles of cable coiled in their holds. About a tenth part of this was payed out, and then the wire broke in deep water; and so ended the first attempt to lay an Atlantic cable. The following year a second expedition started, and after several failures this cable was successfully laid, and England first'spoke electrically to America. The life of this cable was, however, pitifully short; the signals grew weaker and weaker, and after one little month it died. It was not, indeed, until 1866 that a complete cable was laid by the Telegraph Construction and Maintenance Company, which also in the same year captured a cable that had been previously broken and lost. Thus two good cables were completed between England and America.

Prof. Ayrton then described the siphon recorder in some detail, and exhibited the earliest example of that instrument, constructed in I870. Later forms were also shown, in which the electrified ink was replaced by the use of a vibrating siphon. The system of automatic sending was explained, and the question of signalling briefly considerecl, diagrams being thrown on the screen illustrative of the effect of condensers and of curbing in obtaining sharp signals. The word "imperial" was sent by an automatic sender at the rate of seventy-two letters a minute through the artificial Pacific cable in four different ways: (I) with no curbing nor condensers at either end ; (2) with curbing only; (3) with condensers only; (4) with curbing and condensers at both ends of the cable.

Before concluding his lecture, Prof. Ayrton, not content with having his subject limited to the space of sixty years, looked ahead and saw, or rather failed to see, the cables of the future. For it is his belief that in the days to come copper conductors, gutta-percha insulation, and iron wire-sheathing will be relegated to the museum of antiquity, and when a person wishes to telegraph to a friend, he knows not where, he will call to him in an electromagnetic voice, which will be heard distinctly by him who has the electromagnetic ear, but will be silent to every one else !

The hall was hung with the portraits of the chief of the early workers in submarine telegraphy, each in its turn being illum inated with a projector when reference was made to it; the lecture was illustrated with historical letters and documents, specimens of all the important early cables, as well as of the latest, hydraulic and other models; and an artificial cable elec. trically 3600 miles long, fitted up with signalling apparatus at each end, was shown through the kindness of Dr. A. Muirhead.

Mr. Preece was unfortunately absent through illness, but his place as Chairman was filled by Sir Henry Mance. Thus a compensation was afforded in having an opportunity of admiring not Mance's method of finding faults, but his method of finding merits in Prof. Ayrton's sixty years of cable.

\section{THE VALUE OF IRRIGATION CANALS IN INDIA.}

THE deplorable state of large districts in India at the present time is attracting a great deal of attention, owing to the famine which is devastating the country, caused by the failure of the crops from the drought and want of rain. Under such conditions, every drop of water is as precious as gold, and the canal authorities have to strain every nerve to make the avail. able water supply spread as far as possible. Any information bearing on the canals cannot fail, at such a time, to be of interest. A return recently issued by the Public Works Department bears testimony not only to the great benefit that has already been conferred on India by the system of irrigation pursued during recent years by the Indian Government, but also shows that these works have been a financial success.

Lord Lansdowne is reported strongly to have urged that public works of irrigation do more good than any other form of public works; and it is a matter of regret that more has not been done in the past in the matter of canal construction. The total area irrigated in India from Government works is about I $3 \frac{1}{2}$ millions of acres, the estimated value of the crops raised on this area amounting to $37,000,000 l$., taking a crore of

NO. I 426 , VOL. 55$]$ 
rupees at $1,000,000 l$., up to the end of 1895 , as far as the report goes. A sum of $29 \frac{1}{2}$ millions of pounds had been expended on the construction of 37 works, which brought in a net revenue of 4.32 per cent. on the total capital expended, although some of the works were not then completed. Of these, the Madras canals paid 6.75 per cent. ; the Sind, 6 per cent. ; the Northwestern Provinces, $5^{*} \cdot 22$ per cent. ; the Punjab, $4^{*} 33$ per cent. ; Deccan and Goojerat, I'I8 per cent. ; and Bengal, less than one-tenth per cent. The general deductions to be drawn from the figures given in the report are that, while these irrigation canals have been of inestimable value to the productive resources of India, and in mitigating the direful effects of famines, the expenditure has at the same time proved very remunerative; and that though the Bengal and Bombay canals have been unremunerative, and are never likely to pay, still the works in the other provinces have more than compensated for these losses. The results from minor works, or those constructed out of revenue, are even more satisfactory. Seventy of these works have cost about 3,000,000/, and irrigate 2,194,44I acres, the net revenue yielding $\mathrm{x} \cdot{ }^{\circ} 6 \mathrm{I}$ percent. on the outlay. The annual allotments for these works have in recent years been $360,000 l$. of which about $240,000 l$. is expended on up-keep. In view of their remunerative character and immense benefit to the natives, the policy of expending large sums in relief works, and extending the system of irrigation in seasons of drought, as is now being done, must commend itself as being sound legislation. There is a third class of canals, known as "protective" works, the cost of which is charged to the funds set apart for protection from, or the mitigation of, famines. These have cost about $2,000,000 l$. They are principally designed to provide against seasons of drought. Up to the present they have only brought in a return of I per cent. on the outlay. They cannot, however, be looked at from a commercial standpoint, but rather on their value in years of drought; whereas the year to which the return relates was one of considerable rainfall. If, during the present season of drought, they have aided in mitigating the effect that otherwise would have followed in the districts where they are situated, they will have accomplished the object for which they were constructed, although they may not prove commercially productive.

\section{UNIVERSITY AND EDUCATIONAL INTELLIGENCE.}

Cambringe.-Mr. W. F. Sedgwick, bracketed Senior Wrangler, 1894, has been elected to an Isaac Newton Studentship in Astronomy.

The General Board of Studies has published the proposed regulations for the admission of Advanced Students to certain Triposes. In general the standard to be required from such students is that of a second class in Part ii. of the Tripos. In Natural Sciences a first class in a single subiect of Part ii. will be expected.

The Board of Supervision for Indian Civil Service students is about to be formally constituted a Special Board of Studies, with the same status and privileges as the other Special Boards.

Honorary degrees are to be conferred, at the congregation on March II, on the French Ambassador (Baron de Courcel) and the American Ambassador (Mr. Bayard), and also on Dr. Zahn of Berlin, and Prof. Klein of Göttingen. Dr. Nansen cannot attend on that day, and will accordingly be admitted on March 16.

The following have been appointed Electors to the respective professorships mentioned. Plumian of Astronomy, Prof. $\mathrm{H}$. H. Turner; Anatomy, Sir W. H. Flower; Downing of Medicine; Dr. S. Ringer ; Cavendish of Physics, Prof. A. W. Ruicker; Mechanism and Applied Mechanics, Sir F. J. Bramwell ; Surgery, Prof. Allbutt ; Pathology, Dr. D. MacAlister.

The Hartley College, Southampton, has received a valuable addition to its library in the form of a complete series of the "Challenger Reports," presented by the Government at the representation of the Royal Society.

Ar a meeting of the London County Council on Tuesday, the recommendation of the Technical Education Board, asking the Council for the sum of $f_{150}, 000$ from the Customs and Excise dues, for the purpose of technical education in London during the year $1897-98$, was agreed to.

$$
\text { NO. I 426, VOL. } 55]
$$

AT the last meeting of the Council of Bedford College, London, the following resolution was passed unanimously: "That the Council and Teaching Staff of Bedford College, London, express the earnest hope that IIer Majesty's Government will at an early date again introduce a Bill for the creation of a Statutory Commission for the reconstitution of the University of London on the lines indicated by Lord Cowper's Commission, and assure the Government that such a measure will have their active support."

Science announces the following gifts to education in the United States:- The will of the late Mrs. Horatio Lyon, of Springfield, Mass., gives, among other public bequests, I0,000 dols. to Monson Academy, Io,00o dols. to Pomona College, and Io, ooo dols. to Menden Free Library.-Harvard University has received from Mr. J. Howard Nichols 5000 dols. to be used to found a new scholarship, preference being given to a student from the State of Alabama. - The will of the late Charles Willard, of Battle Creek, Mich., leaves 40,000 dols. to the Bap. tist College at Kalamazoo, Mich., and 40,000 dols. for a library building for the city schools at Battle Creek, Mich.

WE are glad to see that the University colleges are to be given an additional grant by the Government. The increase was announced in the House of Commons on Monday, when Sir W. Houldsworth (Manchester, N.W.) asked the Chancellor of the Exchequer whether any report had yet been received from the Commissioners appointed by him to visit the University colleges which received a Government grant, and, if so, whether there was any prospect of these colleges, or any of them, receiving an augmented grant in the next financial year. The Chancellor of the Exchequer replied to the first question in the affirmative, and he pointed out that an additional grant of 69500 for the University Colleges appears in the Civil Service Estimates.

THE Foumal of School Geography, the first number of which has just been published at Lancaster, Pennsylvania, U.S.A., should be a real source of help and a valuable geographical aid to teachers in elementary and secondary schools. The aim of the new periodical is to present the newest and best geographical information in such a form that it can be readily used for teaching purposes. The responsible editor is Prof. Richard E. Dodge, Teachers' College, New York City, and associated with him are Prof. W. M. Davis, Mr. C. W. Hayes, Prof. H. B. Kummel, Dean McMurry, and Mr. R. de C. Ward. Natural science, physical geography, geology, physiography, pedagogy, and climatology are thus all represented upon the editorial staff, so that attention to all the phases of the broad science of geography is ensured. The new journal should be of great assistance in advancing geographical knowledge, and in making the study of the earth a means of developing the habit of observation.

THE following are among recent appointments:-Prof. Francis E. Lloyd to be professor of biology in the Teachers' College, New York; Dr. Alexander P. Anderson to be professor of botany at Clemson College, S.C. ; Postmaster-General Mr. L. Wilson to be president of the Washington and Lee University at Lexington, Kentucky; Dr. Chr. Nussbaum to be professor of hygiene in the Technical High School at Hanover; Dr E. Wiechert, privat-docent in mathematical physics at Königsberg, to be titular professor; Dr. J. Liznar to be professor of meteorology at Vienna ; Hon. James Wilson, director of the Iowa Agricultural Station and professor of agriculture in the Iowa Agricultural College, to be Secretary of Agriculture in the United States; Dr. L. A. Bater to be assistant professor of mathematics and mathematical physics in the University of Cincinnati; Dr. L. F. Barker to be assistant professor of anatomy in the Johns Hopkins University (Baltimore).

Iv a valuable and well-considered report upon the work accomplished last year, under the auspices of the Technical Education Committee of the Derbyshire County Council, Mr. Percy Hawkridge shows that in his county a very great develop. ment of classes for industrial students has taken place since the advent of the County Council into the educational field. In I 890-9I there were 700 students attending elementary science classes in Derbyshire; in $1891-92$, when the County Council education scheme came into force, there were 1325 students and in I 894-95 the number was 2342. This great development has taken place although classes not connected with local 